\title{
Guidance in the ages of neuroscience
}

\author{
Lefteris Lykouras \\ From $1^{\text {st }}$ International Congress on Neurobiology and Clinical Psychopharmacology and European \\ Psychiatric Association Conference on Treatment Guidance \\ Thessaloniki, Greece. 19-22 November 2009
}

Over the past two decades important progress has been made in the area of intervention in psychiatric disorders, mainly with the introduction of novel antidepressant and antipsychotic drugs. Despite these advances, the interindividual differences in the psychotropic drug response and the development of drug-induced adverse effects remain a serious problem in clinical practice. On the other hand, more information about the mechanisms of action of psychotropic drugs may help the way they should be prescribed. In this regard application of technological advances in the field of neurosciences, namely modern neuroimaging methods and the enormously developed molecular genetics acquires paramount importance. PET and SPECT studies have indicated that antipsychotic response is associated with blockade of dopamine D2 receptors and antidepressant response has been linked to blockade of serotonin transporter receptors. According to Zipurski et al (2007), these findings have the following clinical implications: a) antipsychotic dosing for most patients with schizophrenia can be expected to occur within a narrow range of D2 receptor blockade, (b) Antidepressant response for must patients can be expected to occur with blockade of $80 \%$ or more of the serotonin transporter. Pharmacogenetics and pharmacogenomics signal the beginning of a new era in the treatment psychiatric disorders. They provide a novel method in the search of informative correlates of psychotropic drug response. Polymorphisms of dopamine and serotonin receptor subtypes, transporter proteins and metabolic enzymes may contribute to variability in response to psychotropic drugs and the occurrence of their adverse reactions. In the field of molecular biology, it has been demonstrated that psychotropic drugs used to treat mood disorders, target molecules and signaling cascades implicated in the control of neuroplasticity. Our expanding knowledge of

Director of the 2nd Department of Psychiatry, Attikon Hospital, School of Medicine, Athens University, Greece psychopharmacology will help lead to specific targeting for more predictable and safer medications in the near future. It is believed that perspectives are outstanding to achieve benefits previously unattainable.

Published: 22 April 2010

\section{References}

1. Bolonna AA, Arranz MJ, Mancama D, Kerwin RW: Pharmacogenomics - can genetics keep in the care of psychiatric patients? Intern Rev Psychiatry 2004, 16:311-319.

2. Schloesser RJ, Huang J, Klein PS, Manji HK: Cellular plasticity cascades in the pathophysiology and treatment of bipolar disorders. Neuropsychopharmacology Rev 2008, 33:110-133.

3. Zipurski RB, Meyer JH, Verhoeff NP: PET and SPECT imaging in psychiatric disorders. Can J Psychiatry 2007, 52:146-157.

doi:10.1186/1744-859X-9-S1-S45

Cite this article as: Lykouras: Guidance in the ages of neuroscience.

Annals of General Psychiatry 2010 9(Suppl 1):S45.

Submit your next manuscript to BioMed Central and take full advantage of:

- Convenient online submission

- Thorough peer review

- No space constraints or color figure charges

- Immediate publication on acceptance

- Inclusion in PubMed, CAS, Scopus and Google Scholar

- Research which is freely available for redistribution

Submit your manuscript at www.biomedcentral.com/submit 